\title{
Przywileje dzielnicowe Wielkiego Księstwa Litewskiego. Stan i perspektywy badań
}

Mianem przywilejów dzielnicowych Wielkiego Księstwa Litewskiego określa się w historiografii dokumenty wydawane przez wielkich książąt litewskich społecznościom poszczególnych ziem (regionów) tego państwa. Dokumenty te regulowały zarówno różne aspekty stosunków ludności z wielkimi książętami i ich namiestnikami (wojewodami), jak też ustrój i prawo danej ziemi. Wydawanie przywilejów zaczęło się najpóźniej w latach 40. XV w. ${ }^{1}$, natomiast moc zachowały one aż po XVII stulecie. Najdawniejszy oryginał takiego dokumentu - przywilej nowogródzki z 1440 r. - określony jest we własnej treści jako gramota bądź list. Jest to charakterystyczne dla wszystkich kategorii dokumentu pisanego w Wielkim Księstwie Litewskim, natomiast określenie przywilej utrwaliło się w nauce dzięki potwierdzeniom z początku i pierwszej połowy XVI w., które zresztą również zachowują nazwę list. Słowo przywilej przeniknęło do ruszczyzny poprzez język polski (z łac. privilegium $^{2}$ ) dosyć wcześnie, nie później niż w połowie XIV w. Już wtedy oznaczało jakikolwiek pisany dokument, nie tylko nadający wyłączne prawo jakiejś osobie, grupie osób, korporacji itd. ${ }^{3} \mathrm{~W}$ tym szerokim znaczeniu spotykamy je w Księdze nadań Kazimierza - najdawniejszej księdze Metryki

\footnotetext{
*Artykuł powstał $\mathrm{w}$ ramach stażu podoktoranckiego na Uniwersytecie Wileńskim (projekt Kształtowanie się systemu zarządu ziemiami ruskimi Wielkiego Księstwa Litewskiego w XIV-XVw.), finansowanego w ramach projektu funduszy strukturalnych Unii Europejskiej Realizacja stażów podoktoranckich (postdoc) na Litwie.

${ }^{1}$ Większość przywilejów dzielnicowych zachowała się w potwierdzeniach z początku - pierwszej połowy XVI w., jednak wielcy książęta litewscy zaczęli wydawać takie dokumenty znacznie wcześniej (o czym niżej).

${ }^{2}$ Szerzej: M. Wąsowicz, Od privi leges do Karty Komuny. Z dziejów przywileju w średniowiecznej Europie, „Czasopismo Prawno-Historyczne” LI: 1999, z. 1-2, s. 77-94; o przywilejach szlacheckich zob.: M. Bush, Noble Privilege, Manchester University Press 1983, a dla stosunków polskich: W. Uruszczak, Species privilegium sunt due, unum generale, alius speciale. Przywileje w dawnej Polsce, [w:] ,Studia z Dziejów Państwa i Prawa Polskiego” T. XI: 2008, s. 19-38.

${ }^{3}$ В. Розов, Украйнські грамоти, Т. 1, Київ 1928, nr 6, s. 12 (1366 r.).
} 
Litewskiej z XV w. ${ }^{4}$ Aby odróżniać przywileje nadane ziemiom Wielkiego Księstwa Litewskiego od innych typów dokumentów, te pierwsze historycy jeszcze w XIX w. określili jako dzielnicowe. Jest to nazwa umowna, nie źródłowa, wnosi jednak niezbędną precyzję terminologiczną.

Badania przywilejów dzielnicowych ostatnio rozszerzyły swą tematykę, odnaleziono nowe archiwalia, zrewidowano niektóre tradycyjne poglądy. To wszystko wymaga ukazania historii badań. Pozwoli to podsumować wyniki i możliwości dalszych poszukiwań, zwłaszcza że w pracach o historiografii Wielkiego Księstwa Litewskiego problemu nie doceniono. Szkic niniejszy ograniczy się jedynie do prac specjalnie poświęconych przywilejom lub wnoszących istotny wkład w ich badanie.

Pierwsze edycje przywilejów dzielnicowych, udostępniające je badaczom, ukazały się w pierwszej połowie XIX w. - najpierw w Zbiorze Muchanowa (1836), następnie w Zbiorze praw litewskich Tytusa Działyńskiego oraz Aktach, odnoszacych się do historii Rosji Zachodniej protojereja Iwana I. Grygorowicza. Niemal wszystkie wydano na podstawie kopii przechowanych w Metryce Litewskiej. Teksty przywilejów dla Żmudzi zebrał Szymon Dowkont (Simonas Daukantas), pracujący w latach 1837-1850 jako pomocnik metrykanta w Senacie Rządzącym w Petersburgu, jednak przygotowanego przez niego zbioru nie wydano. Nie opublikowano również tekstów przywilejów dla innych ziem Wielkiego Księstwa Litewskiego, których odpisów udzielił on Teodorowi Narbuttowi, nie wykorzystano ich też w jego Dziejach narodu litewskiego 5 . Dopiero po śmierci Dowkonta ukazał się Skarbiec diplomatów Ignacego Daniłowicza (1788-1843), który zawierał też dane o niektórych przywilejach dzielnicowych.

W latach 60. XIX w. pojawiło się w Imperium Rosyjskim zainteresowanie nie tylko edytorów, ale też historyków pomnikami prawa - wśród nich przywilejami dzielnicowymi - Wielkiego Księstwa Litewskiego. Przyczyną tego był, z jednej strony, ogólny wzrost zainteresowania historią prawa pod wpływem nie tylko historycznej szkoły prawa, ale również prac kodyfikacyjnych lat 30. XIX w. Z drugiej zaś strony - po powstaniu styczniowym historycy otrzymali zadanie „opanowania” ziem litewskich z punktu widzenia „russkogo dieła". U podstaw ówczesnych prac leżała tzw. teoria wspólnotowo-wiecowa czy ziemsko-wiecowa, sięgająca dychotomii ziemi (tj. społeczeństwa) i państwa, którą jeszcze za panowania Mikołaja I zaproponował słowianofil Aleksy S. Chomiakow, opracował zaś zwolennik jego teorii Konstanty S.

${ }^{4}$ Lietuvos metrika. Knyga Nr. 3: (1440-1498); Užrašymų knyga 3, wyd. L. Anužytė, A. Baliulis, Vilnius 1998, s. 17, 24, 29, 63, 64.

${ }^{5}$ Z. Kiaupa, Simono Daukanto parengti Lietuvos Metrikos medžiagos rinkiniai, [w:] Lietuviu atgimimo istorijos studijos. T. V: Simonas Daukantas. Vilnius 1993, s. 108, 110-114; Žemaitijos žemés privilegijos XV-XVII a. Privilegia terrestria Samogitiensia, wyd. D. Antanavičius, E. Saviščevas, Vilnius 2010, s. 23. 
Aksakow $^{6}$. W latach 60. XIX w., m.in. dzięeki pracom Iwana D. Bieliajewa ${ }^{7}$, a później Wasyla I. Siergiejewicza, utrwaliło się wyobrażenie o jedności $l u d u$, który nie znał podziału stanowego, oraz o formie jego bytu politycznego - wiecu, który zawierał umowy z księciem ${ }^{8}$. Ważnym impulsem dla upowszechnienia tych idei nawet wśród historyków niebędących słowianofilami stały się wielkie reformy z lat 60. XIX w. Nadawała się do tego wizja Wielkiego Księstwa Litewskiego jako państwa litewsko-ruskiego, które długo zachowywało żywotne zasady ruskie: brak podziału stanowego i prawosławie, uległo jednak wpływowi zasad polskich - stanowości, przywilejom szlacheckich, prawu niemieckiego w miastach, katolicyzmowi - co też doprowadziło do jego upadku.

Teoria wspólnotowo-wiecowa zyskała prawo trwałego obywatelstwa też wśród badaczy kijowskiego Uniwersytetu św. Włodzimierza, gdzie w latach 60. XX w. zaczęto szczegółowo badać przywileje dzielnicowe Wielkiego Księstwa Litewskiego. Badania rozpoczęli historycy tzw. kijowskiej szkoły zachodnioruskiego prawa ${ }^{9}$ - Fiodor I. Leontowicz (1833-1911), mianowany prywat-docentem, a później profesorem, oraz student wydziału prawa F. Czarnecki. W pracy poświęconej porównaniu Prawdy Ruskiej i Pierwszego Statutu Litewskiego 1529 r. F.I. Leontowicz przytoczył listę znanych przywilejów dzielnicowych i sklasyfikował ich tematykę (prawa kościelne, stosunki stanowe, prawo cywilne i kryminalne, proces sądowy) ${ }^{10}$. Podstawowa teza pracy to udowodnienie długiego panowania w Wielkim Księstwie Litewskim prawa wzorowanego na Prawdzie Ruskiej, w kształcie czystym i omal niezmienionym. Z Prawdy Ruskiej Leontowicz wywodził zasady zarówno Pierwszego Statutu Litewskiego, jak i przywilejów dzielnicowych (w tym - podlaskich, bazujących na statutach Kazimierza Wielkiego i Władysława Jagiełły ${ }^{11}$ ). Wpływu prawodawstwa polskiego dopatrywał się natomiast $\mathrm{w}$ artykułach poświęconych prawom bojarstwa i szlachty. Jednak oddziaływanie

${ }^{6}$ М.Б. Свердлов, Общественный строй Древней Руси в русской исторической науке XVIII-ХХ веков, Санкт-Петербург 1996, s. 81-83, 88-90, 92; Н.И. Цимбаев, Славянофильство. Из истории русской общественно-политической мысли ХІХ века, Москва 1986, rozdz. 4.

${ }^{7}$ Е.Н Дербин, Земско-вечевая теория политического устройства Древней Руси и время её возникновения, [w:] Социальная мобильность в традиционных обществах: история и современность, Ижевск 2012.

${ }^{8}$ М.Б. Свердлов, op. cit., s. 100 i nn.; П.В. Лукин, Вече: социальный состав, [w:] А.А. Горский, В.А. Кучкин, П.В. Лукин, П.С. Стефанович, Древняя Русь: Очерки политического и социильного строя. Москва 2008, s. 34-35.

${ }^{9}$ Zob.: С.И. Михальченко, Киевская школа в российской историографии (икола западно-русского права), Москва-Брянск 1996; Т. Бондарук, Західноруське право: дослідження і дослідники (Київська історико-юридична школа), Київ 2000.

${ }^{10}$ Ф.И. Леонтович, Русская правда и Литовский статут, в видах настоятельной необходимости включить литовское законодательство в круг истории русского права, „Университетские известия”, Киев (dalej: УиК), 1865. Nr 2. 4-я паг., s. 7-8.

${ }^{11}$ Ibidem, s. 10-12. 
tego prawa uznawał - najogólniej - za nieznaczne, zaś przywileje dzielnicowe - za narzędzie obrony tradycyjnych instytucji ruskich - stariny ${ }^{12}$. Zaznaczał przy tym, że przywileje stanowiły wyjątki od praw ogólnych - samej Prawdy Ruskiej ${ }^{13}$. Tego, w jaki sposób zarówno prawa, jak i wyjątki od nich mogły bazować na tym samym systemie prawnym, F.I. Leonowicz jednak nie wyjaśnił. Ponadto zaznaczył, że pierwsze przywileje dzielnicowe wydane przez Witolda i Kazimierza Jagiellończyka zachowały się tylko w późniejszych potwierdzeniach, nie podejmował wszakże prób datacji ani powiązania ich z historią polityczną.

Praca F. Czarneckiego, opublikowana w tych samych latach, w zasadzie sprowadzała się do wyliczenia i systematyzacji danych o pomnikach prawodawstwa Wielkiego Księstwa Litewskiego przed Pierwszym Statutem Litewskim oraz streszczenia ich zasad ${ }^{14}$. Autor jej, tak jak Leontowicz, wychodził z założenia o długim zachowaniu staroruskich zasad w prawie Wielkiego Księstwa Litewskiego, pomimo wpływu „zasad destrukcyjnych” cywilizacji polskiej; z punktu widzenia naukowego uważał za wskazane „ostateczne wykazanie jedności litewskiego bytu prawnego ze staroruskim i wskazanie prawodawstwu litewskiemu należytego miejsca w historii prawa ruskiego" [podkr. - S. P.] ${ }^{15}$. F. Czarnecki odnotowywał wprawdzie wzmianki o niezachowanych przywilejach dzielnicowych w zachowanych, jednak nie próbował rekonstrukcji ich treści ani datacji. Przy tym podkreślał konserwatyzm prawa Wielkiego Księstwa Litewskiego, stałe odwołanie się do stariny oraz jego partykularyzm: akty ustawodawcze od końca XIV w. były przeznaczone dla poszczególnych ziem, miast, stanów i grup ludności. Dopiero w trzeciej dekadzie XVI w. Wielkie Księstwo Litewskie dojrzało do przyjęcia kodeksu ogólnopaństwowego, co pozwoliło na ujednolicenie praw różnych kategorii szlachty, natomiast brak kodyfikacji nasilał niesprawiedliwość ${ }^{16}$.

W nauce ówczesnej stopniowo utrwalał się pogląd, że litewskie przywileje dzielnicowe należą do kategorii źródeł prawa ruskiego, to przyczyniło się więc do rozwoju studiów nad nimi. Świadczy o tym włączenie ich do II wydania 2. części Wypisów z historii ruskiego prawa innego profesora Uniwersytetu św. Włodzimierza - Michaiła F. Władimirskiego-Budanowa (1836$-1916)^{17}$. Pionierem ich szczegółowego badania stał się jego uczeń, znany

12 Ibidem, s. 7-9.

13 Ibidem, s. 4.

14 [Ф.] Чарнецкий, История Литовского Статута, с объяснением особенностей трех его редакций и предварительным обозрением законодательных памятников, действовавщих в Западной России, до издания Статута, УиК, 1866, № 9, s. 1-46; 1867, № 1, s. 1-36; № 5, s. 1-22; № 6, s. 1-30; № 7, s. 1-34; № 8, s. 1-37; № 9, s. 1-50; № 10, s. 1-45.

15 [Ф.] Чарнецкий, op. cit., УиК 1866, № 9, s. 3-4.

16 [Ф.] Чарнецкий, op. cit., УиК, 1867, № 10, s. 1-6.

${ }^{17}$ М.Ф. Владимирский-Буданов, Христоматия по истории русского права, t. II, wyd. 2, Киев 1879, s. 46 i nn. 
później historyk prawa Michaił N. Jasinski (1862-1935), który poświęcił im studium kandydackie (doktorskie) opublikowane w 1889 r. ${ }^{18}$ Przede wszystkim sklasyfikował przywileje wielkich książąt litewskich, dzieląc je według obszaru ich obowiązywania ${ }^{19}$, co pozwoliło mu wyodrębnić przedmiot badania - dokumenty określające stosunek poszczególnych ziem do państwa jako całości ${ }^{20}$. Nazwał je ustawnymi ziemskimi gramotami. Ten termin, z jednej strony, odpowiadał dokumentom państwa moskiewskiego o tej nazwie, z drugiej zaś - podkreślał ich znaczenie dla całości społeczeństwa tej czy innej ziemi Wielkiego Księstwa Litewskiego, a nie tylko pewnego stanu, korporacji czy warstwy społecznej. Według ostatniego kryterium ustawnyje ziemskije gramoty przeciwstawiał przywilejom szlacheckim. Tym ostatnim niechętnie przyznawał prawo do miana przywilejów ziemskich, wydawano je bowiem nie całej ludności, a jedynie wąskiej grupie osób ${ }^{21}$. Zdaniem Jasinskiego i zgodnie z opisaną wyżej teorią - gdy gramoty szlacheckie i przywileje dla miast na prawo magdeburskie oraz dla Żydów wprowadzały nowe, stanowe porządki, to ustawnyje ziemskije gramoty były kierowane do całego regionu, a ich zadaniem było zachowanie miejscowej stariny ${ }^{22}$. Podział dokumentów według kryterium ich ogólnego i prywatnego znaczenia był sam w sobie sensowny. Pozwalał bowiem wyodrębnić przywileje dzielnicowe jako przedmiot zainteresowania historiografii - o czym świadczy klasyfikacja źródeł prawa u F. Czarneckiego oraz opinia F.I. Leonowicza (o której niżej), jednak absolutyzacja tego podziału może doprowadzić do absurdu: oto właśnie z prywatnych przywilejów powstały dzielnicowe dla ziemi smoleńskiej i Żmudzi, a niemało zasad przywilejów dzielnicowych znajduje dokładną analogię w dokumentach hospodarskich skierowanych do miast.

Idąc dalej, M.N. Jasinski zadał sobie pytanie o genezę ustawnych ziemskich gramot. Ocenił, że wydawano je podczas likwidacji księstw dzielnicowych, aby osiągnąc kompromis z miejscową ludnością ${ }^{23}$. W epoce Witolda usytuował wydanie przywilejów połockiego, witebskiego, smoleńskiego, żmudzkiego oraz kijowskiego ${ }^{24}$, w epoce Kazimierza - wołyńskiego ${ }^{25}$, w epoce Aleksandra - przywileju dla powiatu bielskiego na Podlasiu ${ }^{26}$. Uczony też pokusił się o datację dopełnienia tych przywilejów nowymi normami: przywileje połocki i witebski potwierdzano i uzupełniano za Świdrygiełły, Zygmunta 1889.

${ }^{18}$ М.Н. Ясинский, Уставные земские грамоты Литовско-Русского государства, Киев

\footnotetext{
${ }^{19}$ Ibidem, s. 9 i nn.

${ }^{20}$ Ibidem, s. 30.

${ }^{21}$ Ibidem, s. 16-20.

${ }^{22}$ Ibidem, s. 30-33, 73-74

${ }^{23}$ Ibidem, s. 47 i nn.

${ }^{24}$ Ibidem, s. 53, 56-57, 60, 62, 66.

${ }^{25}$ Ibidem, s. 71.

${ }^{26}$ Ibidem, s. 72 .
} 
Kiejstutowicza, Kazimierza i Aleksandra ${ }^{27}$, smoleński i żmudzki - za Zygmunta i Kazimierza ${ }^{28}$, kijowski - za Kazimierza i Aleksandra ${ }^{29}$, wołyński zaś - za Aleksandra $^{30}$. Podstawą jego wniosków stały się powołania na odpowiednich wielkich książąt w tekstach tych źródeł, dane o historii politycznej regionów oraz ich język. Na jego archaizm badacz zwrócił uwagę w przypadku przywilejów połockiego i witebskiego. Wszystkie przywileje dzielnicowe M.N. Jasinski podzielił na wszechstanowe, skierowane do różnych grup ludności regionu oraz na szlacheckie (bielski i wołyński) ${ }^{31}$. Długotrwałość obowiązywania przywilejów dzielnicowych tłumaczył on brakiem kodeksu ogólnopaństwowego, którym został dopiero Pierwszy Statut Litewski ${ }^{32}$. W drugiej części swojej pracy M.N. Jasinski sklasyfikował normy przywilejów dzielnicowych.

Niedługo po ukazaniu się książki Jasinskiego do tematyki historii prawa Wielkiego Księstwa Litewskiego powrócił F.I. Leontowicz. Wówczas jednak jego pogląd na przywileje dzielnicowe zmienił się dość istotnie. Gdy wcześniej doszukiwał się on zachowania w nich ruskiej stariny, teraz podkreślał, że jej poszukiwania w nich są daremne. Dokumenty te stanowiły bowiem taką samą nowość, burzącą jedność ziemi - społeczeństwa pewnego regionu, wprowadzającą zaś stany na kształt Polski, jak i przywileje ziemskie (ogólnopaństwowe) dla szlachty ${ }^{33}$. Skoro przywileje dzielnicowe, inaczej niż ustawnyje gramoty Rusi Moskiewskiej, niosły w sobie stanowe zasady, odrzucił Leontowicz termin zaproponowany przez Jasinskiego ${ }^{34}$. Podzielił jednak jego zdanie o wydaniu przywilejów dzielnicowych w miarę likwidacji księstw dzielnicowych i ich włączania do domeny hospodarskiej, którą Leontowicz utożsamiał z „Wielkim Księstwem Litewskim w ściślejszym znaczeniu" ${ }^{35}$. Podchodził on również z rezerwą do datacji niezachowanych przywilejów, zaproponowanej przez Jasinskiego, podkreślił jej hipotetyczność, zauważając, że wzmianka o jakimś władcy nie jest jeszcze tożsama z powołaniem się na jego dokumenty - oznacza bowiem tylko stare zwyczaje, sięgające jego czasów ${ }^{36}$. W zamian jednak zasłużony historyk prawa nie zaproponował niczego, pozostał więc w kręgu tradycyjnych wyobrażeń.

\footnotetext{
${ }^{27}$ Ibidem, s. 54, 56-57.

${ }^{28}$ Ibidem, s. 61-63.

${ }^{29}$ Ibidem, s. 68-69.

${ }^{30}$ Ibidem, s. 71.

${ }^{31}$ Ibidem, s. 78-79.

${ }^{32}$ Ibidem, s. 73-74.

${ }^{33}$ Najszerzej rozwiną swe koncepcje w pracy: Ф.И. Леонтович, Источники литовско-русского права, „Варшавские университетские известия” 1894, № 1. 3-я паг., s. 35-69. Por.: idem, Сословный тип территориально-административного состава Литовского государства и его причинь, „Журнал Министерства народного просвещения” (dalej: ЖМНП), 1895, № 6, s. 385,400 .

${ }^{34}$ Ibidem, s. 38, przyp. 1.

${ }^{35}$ Ф.И Леонтович, Источники литовско-русского права. s. 37-9.

${ }^{36}$ Ibidem, s. 39, 45-46 (przyp. 1), 56-57 (przyp. 1), 59 (przyp. 1).
} 
Bardziej perspektywiczne okazało się podejście M.N. Jasinskiego, dążące do wyodrębnienia etapów rozwoju tekstów przywilejów dzielnicowych i ich datacji na podstawie nie tylko analizy zachowanych tekstów, lecz i historii politycznej regionu. Rozwiną je polski historyk, po studiach w Moskwie i Dorpacie, Jan Feliks Jakubowski (1874-1938) w artykule z 1903 r. ${ }^{37}$ Pierwszą jego część poświęcił przywilejom ogólnopaństwowym - ziemskim, które nieprecyzyjnie określił jako ogólnoziemskie, zaś drugą - dzielnicowym ${ }^{38}$. Pominął polemikę o ziemskim czy stanowym charakterze przywilejów dzielnicowych, proponując natomiast nową metodę ich badań. Porównując między sobą późne (szesnastowieczne) przywileje dla tych samych ziem, zakreślił szczegółowy schemat zmian w ich tekstach również dla okresu wcześniejszego. Rozważania dodatkowo popierał informacjami z dziejów politycznych tych ziem, analizą językową przywilejów oraz porównaniem ich z innymi pomnikami prawa. Za najdawniejsze uznał Jakubowski przywileje dla dzielnic połockiej i witebskiej - za M.N. Jasinskim zwrócił uwagę na archaiczne sformułowania niektórych ich punktów. Pozwoliło to na przeprowadzenie analogii z riadnymi gramotami - umowami Nowogrodu Wielkiego z książętami w wiekach XIII-XIV, a także na datowanie odpowiednich punktów tych przywilejów na pierwszą połowę XIV w., kiedy zawierano z książętami umowę - riad. Na podstawie riadów połockiego i witebskiego powstały zdaniem Jakubowskiego - przywileje Witolda dla tych ziem datowane na lata 1392-1399, pomiędzy podporządkowaniem ich bezpośredniej władzy Witolda a jego wizytą w Połocku, podczas której wydał przywilej kupcom ryskim. Następnie wyodrębnił Jakubowski - powstałe za panowania Świdrygiełły, Zygmunta Kiejstutowicza, Kazimierza Jagiellończyka, Aleksandra Jagiellończyka i Zygmunta Starego - późniejsze dodatki do pierwotnych tekstów przywilejów. Za chronologicznie następny uznawał Jakubowski przywilej Witolda i Jagiełły dla Żmudzi, który datował na rok 1413 - okres chrztu Żmudzi według Jana Długosza. Podstawą dla tych wniosków był przywilej Aleksandra dla Żmudzi z 1492 r., w którym Jakubowski wyodrębnił uzupełnienia Kazimierza Jagiellończyka, związane z powstaniem żmudzkim lat 1441-1442. Powstanie przywileju smoleńskiego badacz datował na 1442 r., gdy Kazimierz podporządkował sobie Smoleńsk po powstaniu 1440 r., zaś drohickiego - na 1444 r. „czy niedługo potem”, gdy władzę Kazimierza uznało Podlasie. Wydanie przywilejów ziemiom łuckiej i kijowskiej słusznie powiązał Jakubowski z likwidacją tamtejszych księstw dzielnicowych, w latach - odpowiednio - 1452 i 1470. Dalsze zmiany w ich tekstach były już nieznaczne.

${ }^{37}$ O nim: T. Manteuffel, Ś. p. Jan Feliks Jakubowski $(1874$ † 1938), „Archeion”, T. XVI: $1938-$ 1939, s. 237-240; idem, Jakubowski Jan Feliks, Polski Słownik Biograficzny, T. X/3, z. 46, Wrocław-Warszawa-Kraków 1963, s. 386.

${ }^{38}$ И.В. Якубовский, Земские привилеи Великого княжества Литовского. [cz. 2], ЖМНП, 1903, № 6. Pierwsza część studium: ibidem, 1903, № 4. 
Wnioski J. Jakubowskiego ówczesna historiografia przyjęła z entuzjazmem. Zaakceptował je więc w pełni Stanisław Kutrzeba, który oparł na nich odpowiedni rozdział w drugim tomie swego zarysu historii ustroju Polski ${ }^{39}$. Zgodnie ze swoją koncepcją podziału administracyjno-terytorialnego Wielkiego Księstwa Litewskiego podzielił przywileje dzielnicowe na dwie grupy. Do pierwszej należały przywileje nadane Żmudzi i Podlasiu, które dzielnice, według niego, wchodziły w skład Litwy ściślejszej i korzystały z przywilejów ogólnopaństwowych, do drugiej zaś - skierowane do ziem ruskich: połockiej, witebskiej, smoleńskiej, łuckiej i kijowskiej, których jakoby nie objęły przywileje ziemskie aż do 1492 r. Tezy Jakubowskiego podzielił Matwiej K. Lubawski, który poparł nimi swoją koncepcję federacyjnego ustroju Wielkiego Księstwa Litewskiego ${ }^{40}$. Spróbował też sprecyzować czas powstania niektórych przywilejów (połockiego, witebskiego i smoleńskiego) poprzez powiązanie ich wydania z sejmem 1451 r., a w dodatku do swojego dzieła opublikował teksty przywilejów do 1569 r. ${ }^{41}$ Stał się więc J. Jakubowski niezaprzeczalnym autorytetem $\mathrm{w}$ tej dziedzinie, jemu też powierzono przygotowanie edycji przywilejów dzielnicowych Wielkiego Księstwa Litewskiego jako dodatku do Akt unii Polski z Litwą. Nie wiadomo, kiedy to nastąpiło: prace nad edycją zaczęły się jeszcze przed I wojną światową i trwały ponad dwie dekady, w ciągu których krajobraz archiwalny Europy Wschodniej zmienił się radykalnie. Dlatego też w 1930 r. pisał on o problemach wynikających z odmowy udostępnienia kopii przywilejów przez władze radzieckie ${ }^{42}$. W każdym razie w opublikowanych dwa lata później Aktach unii materiałów tych nie ma $^{43}$. Plany ich edycji nadal jednak istniały ${ }^{44}$, a przerwała je dopiero śmierć badacza (1938) i wybuch kolejnej wojny.

Jednak już na początku XX w., tuż po pionierskiej pracy J. Jakubowskiego, w badaniach nad przywilejami dzielnicowymi da się zauważyć tendencja odmienna - odrębnych badań w ramach historii poszczególnych ziem Wielkiego Księstwa Litewskiego. Wnioski badacza na temat części składowych przywilejów dzielnicowych i ich datacji podzielili autorzy prac powstałych w pierwszych dekadach XX w., poświęconych historii Żmudzi ${ }^{45}$,

${ }^{39}$ S. Kutrzeba, Historia ustroju Polski w zarysie, T. II: Litwa. Kraków 1914, s. 37-4.

40 М.К Любавский, Очерк истории Литовско-Русского государства до Люблинской унии включительно, wyd. 2 Москва 1915, s. 79-1, 85-4.

${ }^{41}$ М.К. Любавский, Очерк истории, s. 365-01.

42 J. Jakubowski, Archiwum państwowe W. X. Litewskiego i jego losy, „Archeion” T. IX: 1930, s. 9.

${ }^{43}$ Akta unii Polski z Litwą. 1385-1791, wyd. S. Kutrzeba i W. Semkowicz, Kraków 1932.

44 J. Adamus, Wydawnictwa źródel do historii Litwy, [w:] Pamiętnik VI Powszechnego Zjazdu Historyków Polskich w Wilnie 17-20 września 1935 r., T. I: Referaty, Lwów 1935, s. 444, 445; W. Semkowicz, Koreferat, [w:] Pamiętnik VI Powszechnego Zjazdu Historyków Polskich w Wilnie 17-20 września 1935 r., T. II: Protokoły, Lwów 1936, s. 197.

${ }^{45}$ O. Halecki, Litwa, Ruś i Żmudź jako części składowe Wielkiego Księstwa Litewskiego, „Rocznik Akademii Umiejętności w Krakowie” T. LIX (Ser. 2. T. XXXIV), Kraków 1916, s. 29$-30,39-41$. 
Wołynia $^{46}$, Kijowszczyzny ${ }^{47}$, ziemi połockiej ${ }^{48}-$ w których niekiedy zestawiano je w kontekście historii społeczno-politycznej - a także w syntezach dziejów Wielkiego Księstwa Litewskiego. Do korekt ustaleń uczonego jednak nie doszło.

Doprowadziły do nich dopiero nowe odkrycia archiwalne. W 1932 r. historyk litewski Konstantinas Jablonskis opublikował bowiem tekst nieznanego wcześniej przywileju żmudzkiego Kazimierza Jagiellończyka, na podstawie odpisu (aktykacji) w księdze sądu grodzkiego żmudzkiego z $1661 \mathrm{r}^{49}$ Tekst źródła zapisano po polsku z licznymi pomyłkami, co doprowadziło do słusznego wniosku, że jest to dosyć późne tłumaczenie z języka ruskiego. Ponieważ Kazimierz Jagiellończyk użył w nim tytułu królewicza, wielkiego księcia litewskiego, żmudzkiego, ruskiego itd., a przywilej datowano na 5 indykcję (1 września 1441 - 31 sierpnia 1442 r.) - K. Jablonskis datował go na ostatnie miesiące 1441 r. Ściślej: między zawarciem przez bojarów żmudzkich umowy z Kazimierzem, o której wspomina list dostojnika krzyżackiego z 1 października 1441 r., a początkiem stosowania tytułu żmudzki, o którym pierwsza znana wzmianka pochodzi z 11 stycznia 1442 r. Wydanie przywileju historyk słusznie łączył z pojednaniem Żmudzinów z wielkim księciem po powstaniu 1441 r. Doszedł też do wniosku, że w oryginalnym ruskim tekście przywileju była mowa o włości knetowskiej (w polskim tłumaczeniu zniekształcone - włosci Senatorskiey). Widział w tym opuszczenie podczas przepisywania nazw wszystkich innych włości na Żmudzi, do których był skierowany przywilej - wzmiankę o nich zawiera bowiem analogiczny dokument z 1492 r. Zauważył również, że przywilej reguluje stosunki Żmudzinów z władzą wielkoksiążęcą, ale nie dotyczy stosunków wewnątrz bojarstwa: odpowiednie punkty dołączono dopiero w przywileju Aleksandra 1492 r. Już po II wojnie światowej K. Jablonskis opublikował dane o kolejnym odkryciu - przywileju w. ks. Kazimierza dla włości miednickiej na Żmudzi. Wydał zresztą nie sam łaciński tekst, który zachował się w późnym, bardzo zniekształconym odpisie - jego edycja ukazała się dopiero w 2010 r., lecz jego przybliżone tłumaczenie litewskie ${ }^{50}$.

W późniejszej historiografii dwudziestowiecznej - pomimo odkryć K. Jablonskisa - badań nad przywilejami dzielnicowymi Litwy historycznej nie

${ }^{46}$ O. Halecki, Ostatnie lata Świdrygielty i sprawa wołyńska za Kazimierza Jagiellończyka, Kraków 1915.

${ }^{47}$ П.Г. Клепатский, Очерки по истории Киевской земли. Литовский период, Біла Церква 2007 (1. wyd. Одесса 1912), s. 268, przyp. 1178.

48 У.І. Пічэта, Полацкая зямля у пачатку XVI сталещьия, [w:] Чатырохстолецьие беларускага друку, 1525-1925, Менск 1926, s. 76-13 (przedruk: „Arche Пачатак” 2009, № 7 (82), s. 72-117; tłum. rosyjskie: В.И. Пичета, Полочкая земля в начале XVI в., [w:] idem, Белоруссия и Литва в XV-XVI вв., Москва 1960, s. 213-262.

${ }^{49}$ K. Jablonskis, Archyvinės smulkmenos, „Praeitis” T. II: 1933 (Kaunas), s. 423-427.

${ }^{50}$ Lietuvos TSR istorijos šaltiniai, T. I: Feodalinis laikotarpis, Vilnius 1955, № 194, s. 157. 
prowadzono. Zaważyły na tym takie czynniki, jak bariera językowa, „waga” pracy J. Jakubowskiego oraz specyficzny charakter badań nad historią Wielkiego Księstwa Litewskiego. Jego badanie jako jednolitego państwa postrzegano niechętnie, natomiast badania prowadzono $\mathrm{w}$ ramach historiografii narodowych, jako badania przeszłości radzieckich republik: Litwy, Białorusi, Ukrainy. W niej z reguły chodziło o tradycje ogólnoruskie. W takim tonie utrzymany jest komentarz Anny L. Choroszkiewicz do tekstu połockiego przywileju dzielnicowego 1511 r. w jej edycji Polockich gramot XIII - poczatku XVI wie$k u$. Terminy i normy przywileju zestawiono z realiami dokumentów tzw. Rusi Północno-Wschodniej, Północno-Zachodniej i Południowo-Wschodniej tego okresu. Na podstawie terminologii i sformułowań poszczególnych artykułów przywileju uczona pokusiła się o ich datację, podzielając w zasadzie wnioski J. Jakubowskiego. Przywołane przez nią dane potwierdziły jego wnioski: o kunicy wetna jako wynagrodzeniu urzędników książęcych za pojednanie stron sporu wspomina nie tylko artykuł połockiego przywileju dzielnicowego, lecz także dźwińska ustawnaja gramota 1397-1398 r., co świadczy o wczesnej - nie późniejszej niż z czasów Witolda - genezie tego artykułu ${ }^{51}$.

Poszczególne normy przywilejów dzielnicowych zestawiano z normami innych pomników prawodawstwa - tzw. Sudiebnika Kazimierza Jagiellończyka z 1468 r., Pierwszego Statutu Litewskiego 1529 r. oraz umów handlowych. Okazało się, że norma przywileju witebskiego, mówiąca o oddaniu niemajętnego złodzieja skarżącemu, jest bardziej archaiczna, niż ustalona w Sudiebniku kara śmierci. Jest jednak podobna do odpowiedniej normy umowy Smoleńska z Rygą i Gotlandią z 1229 r., która obejmowała także Witebsk. Nie zgadzają się ze sobą też przepisy o losie policznego - rzeczy skradzionych: według przywilejów połockiego, witebskiego i smoleńskiego należało je oddać skarżącemu, natomiast Sudiebnik przewidywał oddanie na dwór książęcy ${ }^{52}$. Rozbieżności te wskazują nie tylko na to, że Sudiebnik nie był - pierwotnie - przeznaczony dla całości ziem Wielkiego Księstwa Litewskiego, ale też na archaiczną genezę norm przywilejów połockiego i witebskiego, z których został przejęty artykuł przywileju smoleńskiego.

Nowy etap badań nad przywilejami dzielnicowymi Wielkiego Księstwa Litewskiego rozpoczął się w ostatniej dekadzie XX w. Cechuje go odkrycie i wprowadzenie do obiegu naukowego nieznanych wcześniej źródeł. W nieuporządkowanej części zespołu 293 (Akty zachodnioruskie) Rosyjskiej Biblioteki Narodowej w Petersburgu odnaleziono nieznany przywilej Kazimie-

51 Полоикие грамотыл, wуd. А.Л. Хорошкевич, Т. V, Москва 1990, s. 21, por.: А.Л. Хорошкевич, Исторические судьбы белорусских и украинских земель в XIV-начале XVI в., [w:] В.Т. Пашуто, Б.Н Флоря, А.Л. Хорошкевич, Древнерусское наследие и исторические судьбы восточного славянства, Москва 1982, s. 113-114, 119-121.

52 И.П. Старостина, Судебник Казимира 1468 г., [w:] Древнейшие государства на территории СССР. 1988-1989, Москва 1991, s. 260-263, 266-267, 303-311. 
rza Jagiellończyka dla ziemi nowogródzkiej, datowany na 22 lipca $1440 \mathrm{r}$. W 1991 r. o sensacyjnym odkryciu powiadomił w prasie Nikołaj W. Nikolajew $^{53}$, zaś tekst opublikował po 6 latach Sergiej G. Žemaitis. Odnaleziony dokument jest interesujący z kilku przyczyn. Po pierwsze: jest to najdawniejszy przywilej dzielnicowy, który zachował się jako oryginał, kolejny taki dokument to przywilej smoleński z 1505 r. Po drugie: szereg jego punktów powtarza przywilej ziemski z 1447 r., przy czym w przywileju nowogródzkim są one sformułowane tak, jakby odnosiły się do całego terytorium państwa. Po trzecie: nic nie wiadomo o późniejszym losie przywileju. Odmiennie niż w przypadku innych podobnych dokumentów, w Metryce Litewskiej nie zachowały się jego potwierdzenia przez wielkich książąt, a los zachowanego pergaminu daje się prześledzić częściowo w XVII stuleciu, następnie zaś dopiero od lat 60. XIX w. Inna P. Starostina podjęła próbę zakwestionowania autentyczności przywileju nowogródzkiego, wskazując, że prawa wolnaja, dobraja, chrestijanskaja, o których zawiera wzmiankę, są niczym innym, jak powtórzeniem norm przywileju ogólnopaństwowego 1447 r. Dalsze badania wykazały jednak, że opinia zbliżona do poglądów J. Jakubowskiego nie przekonuje, natomiast paleografia i dyplomatyka przywileju w pełni odpowiadają końcowi lat 30. albo początkowi lat 40 . XV w. ${ }^{54}$ Sam S.G. Žemaitis tłumaczył wydanie przywileju dążeniem do ,pozyskania namiestnika nowogródzkiego Pietrasza Montygierdowicza przez stronnictwo, z którego inicjatywy odbył się wybór Kazimierza na wielkiego księcia" ${ }^{55}$. Wątpliwości wobec tego ujęcia podniosła Lidia Korczak ${ }^{56}$, nie proponując jednak niczego w zamian. Opublikowany przez Žemaitisa przywilej poznali historycy prawa Wielkiego Księstwa Litewskiego ${ }^{57}$, jednak specjalnego studium nadal brakuje. Tymczasem przywilej jest interesujący nie tylko sam w sobie, ale też inspiruje badaczy do postawienia szeregu istotnych pytań. Co skłaniało wielkich książąt litewskich do wydania i potwierdzania podobnych dokumentów? Jaki był stosunek między normami, które utrwalały przywileje ziemskie (ogólnopaństwowe) i dzielnicowe? W jakim stopniu stosowano je w praktyce? W jaki sposób przekształ-

${ }^{53}$ М. Мікалаеуу, «Чынім правы вольныя...»: (Найдаўнейшы юрыдычны акт Наваградскай зямлі), „Наваградскі кур’ер”, 1991 № 1, s. 5.

54 Dziękuję Aleksandrowi I. Hruszy (Mińsk) oraz Sergiejowi G. Žemaitisowi (Petersburg), którzy nie tylko udostępnili oryginał przywileju i innych dokumentów z nieuporządkowanej części zesp. 293, ale też udostępnili mi niepublikowane wyniki swoich badań.

55 С.Г. Жемайтис, Привилей Новогрудской земле, [w:] Рукописные памятники: Публикации и исследования, С. Петербург 1997, Вып. 4, s. 219.

${ }^{56}$ L. Korczak, Ziemia nowogródzka a przywilej ziemski 1440 r., [w:] Lietuvos Didžiosios Kunigaikštystès istorijos kraštovaizdis: moksliniu straipsniu rinkinys. Skiriama profesorès Jüratès Kiaupienès 65-mečiui, Vilnius 2012, s. 147-157.

${ }^{57}$ Często powołuje się nań Dmytro Waszczuk (zob. niżej). Jednak Eugenijus Saviščevas uważa przywilej za podejrzany, nie jest bowiem poświadczony późniejszą tradycją, Žemaitijos žemès privilegijos $X V$-XVII a., s. 11, odpis 21 . 
cały się one z prawa pisanego w starine? Wreszcie - w jakim stopniu znało je miejscowe społeczeństwo? To wszystko wymaga szczegółowych badań.

Odnalezienie przywileju nowogródzkiego okazało się odkryciem najważniejszym, ale bynajmniej nie jedynym. W 2003 r. Michaił M. Krom opublikował przywilej Zygmunta Starego dla ziemi smoleńskiej 1513 r. ${ }^{58}$, uzupełniający analogiczny dokument jego brata Aleksandra z 1505 r. Pozwoliło to na wyjaśnienie niektórych aspektów funkcjonowania przywilejów dzielnicowych i ich miejsca w świadomości mieszkańców tej dzielnicy. Wreszcie zupełnie niedawno polski historyk Tomasz Jaszczołt znalazł w księdze ziemskiej drohickiej z połowy XVI w., przechowywanej w Narodowym Historycznym Archiwum Białorusi w Mińsku, nowe przywileje: Kazimierza Jagiellończyka dla drohickich ziemian - Polaków z 19 czerwca 1445 r., Aleksandra Jagiellończyka dla ziemi drohickiej z 11 września 1494 r. oraz ich transsumpt Zygmunta Starego z 6 stycznia 1507 r., a także przywilej Zygmunta I Starego z 21 VII 1522 r. określający kompetencje starosty drohickiego w sądownictwie nad tamtejszą szlachtą (nie wspominając nawet o dwóch przywilejach - Zygmunta Starego i Zygmunta Augusta - wydanych ongiś drukiem) ${ }^{59}$. Prawie wszystkie czekają na publikację ${ }^{60}$, tak jak i przywilej smoleński z 1505 r., przygotowany przez niżej podpisanego na podstawie oryginału, przechowywanego w Archiwum Głównym Akt Dawnych w Warszawie ${ }^{61}$. Publikacja nowych źródeł powinna skłonić historyków do powrotu do źródeł już znanych, do ponownego zbadania przywilejów dzielnicowych, które w ciągu ostatnich stu lat prawie nie przyciągały uwagi badaczy ${ }^{62}$. Nawet jednak źródła znane stawiają nowe pytania, zmuszają bowiem do rewizji niektórych wniosków

${ }^{58}$ М.М. Кром, Неизвестный привилей Сигизмунда I Смоленску (1513 год), [w:] От Древней Руси к России нового времени. Сб. ст. к 70-летию А.Л. Хорошкевич, Москва 2003, s. $133-$ 139. Reedycja źródła: М.М. Кром, Меж Русью и Литвой. Пограничные земли в системе русско-литовских отношений конца XV-первой трети XVI в., wyd. 2, Москва 2010, aneks 1, s. 260-263; zob. też s. 188-189.

59 Referat T. Jaszczołta Przywileje wielkich książąt litewskich dla szlachty podlaskiej w latach 1446-1547 na XXII konferencji Komisji Lituanistycznej Polskiej Akademii Nauk (Warszawa, 24 września 2013 r.) oraz informacje ustne autora.

${ }^{60}$ Przywilej Kazimierza Jagiellończyka znajduje się w aneksie pracy doktorskiej T. Jaszczołta, ,Szlachta ziemi drohickiej w XV i początkach XVI w. Zagadnienia społeczne, gospodarcze i genealogiczne", Białystok 2009.

${ }^{61}$ С.В. Полехов, Привилей великого князя литовского Александра для Смоленской земли 1505 г., [w:] Древняя Русь. Вопросы медиевистики (w druku).

${ }^{62}$ Najnowsze prace o przywileju smoleńskim są bowiem w znacznej mierze oparte na ustaleniach uczonych z końca XIX - początku XX w.: M.N. Jasinskiego, M.K. Lubawskiego, Grigorija A. Bugosławskiego i J. Jakubowskiego. Na uwagę zasługuje też zaproponowana przez Giennadija A. Łastowskiego datacja przywileju Kazimierzowego dla tej ziemi: na maj - czerwiec 1447 r., Г.А. Ластовский, Политическое развитие Смоленской земли в конце XIII - начале XVI веков, Минск-Смоленск 2001, s. 89-90), a także analiza przedsięwzięć prawodawczych Kazimierza, Aleksandra i Zygmunta Starego wobec tej ziemi dokonana przez M.M. Kroma, Меж Русью и Литвой, s. 186-189; idem, Неизвестный привилей, s. 133-139. 
wywodzących się z prac M.N. Jasinskiego i J. Jakubowskiego. Jak to się odbywa?

Pierwszym przedmiotem badań na nowym etapie dzięki wysiłkom historyków białoruskich stały się najdawniejsze przywileje dzielnicowe Wielkiego Księstwa Litewskiego - połocki i witebski. Badania Wasila Waronina i Andreja Macuka wykazały, jak na przestrzeni wieków zmieniało się przestrzeganie przywileju połockiego, nakazującego hospodarowi - wielkiemu księciu litewskiemu mianować wojewodę połockiego zgodnie z wola lokalnej szlachty W pierwszej połowie XVI w. bowiem miała ona prawo zażądać jego odwołania, a w drugiej połowie XVII w. elekcja wojewody rzeczywiście odbywała się na miejscowym sejmiku ${ }^{63}$. Jak wykazał M.M. Krom, w pierwszej połowie XVI w. prawo odmowy przyjęcia niemiłego namiestnika z powodzeniem wykonywała też szlachta witebska ${ }^{64}$. Wiele pracy włożył Maksym D. Makaraŭ w uściślenie datacji części składowych przywilejów połockiego i witebskiego $^{65}$. Na nowo wydzielił ich najdawniejsze elementy i zestawił z innymi pomnikami prawa, m.in. $\mathrm{z}$ dokumentami z lat 1498-1510 r. dotyczącymi prawa magdeburskiego w Połocku. Wnioski badacza wydają się - generalnie - wysoce przekonujące - muszą więc być uwzględniane podczas badania historii Połocczyzny i systemu jej prawa. Jednak części ustaleń przyjąć raczej nie można. Wydaje się więc, że trudno wszystkie wzmianki o mieszczanach (miesticzach) datować nie wcześniej niż na trzecią dekadę XV w. W znanych obecnie - bardzo jednak nielicznych - dokumentach dotyczących życia miejskiego terminy te zaczęto wykorzystywać właśnie w tym czasie ${ }^{66}$. Natomiast sam wyraz miesticze był znany na tzw. Rusi Zachodniej już w końcu XIII w. ${ }^{67}$, a termin miasto użyty jest w stosunku do Kijowa w liście Witolda w 1415 r. ${ }^{68}$ Sądząc z utworów latopisarskich powstałych w Smoleńsku w latach 30. i 40. XV w., określenie miesticze było już wtedy dosyć rozpowszechnione, oczywiste dla latopisarza i zrozumiałe dla czytelników ${ }^{69}$. Nie trzeba

${ }^{63}$ В.А Варонін, Палітычны лад Полацкага ваяводства у першай палове XVI cm., „Беларускі гістарычны агляд”, Т. 5: 1998, z. 1 (8), s. 28-30; А. Мацук, Традыцыя выбараў полачкага ваяводы у XVII cm. (паводле Метрыкі ВКЛ), [w:] Актуальныя пытанні вывучэння і выдання Метрыкі Вялікага Княства Літоўскага. Матэрыялы міжнароднай навукова-практычнай канферэнщыі (Мінск, 11-12 лістапада 2003 г.), Мінск 2005, s. 120.

${ }^{64}$ М.М. Кром, Меж Русью и Литвой, s. 182-185.

${ }^{65}$ М. Макараў, Ад пасада да магдэбургіi: правовае становішча насельніцтва местай Беларускага Падзвіння ў XIV- першай палове XVII cm., Мінск 2008, s. 134-159.

${ }^{66}$ Собрание древних грамот и актов городов: Вильны, Ковна, Трок, православньх монастырей, церквей, и по разным предметам, Ч. 1. Вильна 1843, № 2, 4. s. 2, 4-6.

${ }^{67}$ П.В. Лукин, «Мгостичи роусции» во Владимире Вольнском, [w:] История: дар и долг. Юбилейный сборник в честь Александра Васильевича Назаренко, Москва-С. Петербург 2010.

${ }^{68}$ Акты, относящиеся к истории Западной России, Т. 1, С. Петербург 1846, № 25, s. 36.

${ }^{69}$ Полное Собрание Русских Летописей, Т. 35: Летописи Белорусско-Литовские, Москва 1980, s. 59-60, 77-78. 
też - choć tak chciał M. K. Lubawski - wiązać z sejmem 1451 r. dopełnienia przywileju połockiego przez Kazimierza Jagiellończyka. Podobne akcje odbywały się nie tylko na sejmach. Jak wynika z przywileju nowogródzkiego - normy przywileju 1447 r. mogły zostać wprowadzane w poszczególnych ziemiach jeszcze przed tą datą. Wreszcie - dość nieoczekiwanie przedstawia się znaczenie i ewolucja przywileju dzielnicowego w świetle zachowanych dokumentów praktyki prawnej. W 1530 r. mieszczanie połoccy, potomkowie niejakiego Seliwestra, przedłożyli Zygmuntowi Staremu dokument Witolda, $i \dot{z}$ miet pradied ich Sieliwiestr żyti wo wpokoi $w$ miestie naszom Połockom, a nichto ich nie miet wywoditi, prosząc o jego potwierdzenie ${ }^{70}$. Połocczanie mogliby powołać się na przywilej dzielnicowy 1511 r., który nakazywał Połoczanom wsim żiti w Połocku dobrowolno, pokul chto chocziet ${ }^{71}$, tego jednak nie uczynili. W 1558 r. przedłożyli natomiast dokumenty Świdrygiełły i królewicza Kazimierza o wyzwoleniu od opłaty myta na całym terytorium Wielkiego Księstwa Litewskiego ${ }^{72}$. Skoro odpowiedni punkt zawiera przywilej 1511 r. - M. Makaraŭ widzi w tych dokumentach wcześniejsze przywileje dzielnicowe, wydane przez tych książą ${ }^{73}$. Jednak wydaje się, że były raczej specjalne dokumenty $\mathrm{w}$ tej kwestii. Więc obok przywileju dzielnicowego istniały - i były wykorzystywane - odrębne dokumenty, które powtarzały i uzupełniały ich treść. Niemniej, jak pokazał M. Makaraŭ, treść przywilejów dzielnicowych była znana Połocczanom i Witebszczanom, zachowały one moc po wprowadzeniu w życie kodeksu ogólnopaństwowego - Pierwszego Statutu Litewskiego 1529 r., oraz prawa magdeburskiego w Połocku (1498) i Witebsku $(1597)^{74}$.

Szczegółowe badania przywilejom kijowskiemu i wołyńskiemu poświęcił Dmytro W. Waszczuk ${ }^{75}$. Zaproponował on datację przywileju kijowskiego nie na 1471 r., lecz wcześniej - na 1440 r., gdy Kijowszczyznę przekazano Olelkowi Włodzimierzowiczowi. Oparł ten wywód, po pierwsze: na podobieństwie norm przywilejów kijowskiego, nowogródzkiego 1440 r. oraz ogólnopaństwowego 1447 r., po drugie zaś: na wątpliwościach co do statusu Olelki Włodzimierzowicza jako księcia dzielnicowego. Jednak - obie te przesłanki

${ }^{70}$ Lietuvos Metrika. Knyga 224 (1522-1530); 4-oji Teismu bylu knyga, wyd. S. Lazutka et al., Vilnius 1997, № 469, s. 379.

${ }^{71}$ Полочкие грамоты, wyd. А.Л. Хорошкевич, Т. ІІІ, Москва 1980, № 323.

${ }^{72}$ Полочкие грамоты, wyd. А.Л. Хорошкевич, Т. II, Москва 1978, № 244.

${ }^{73}$ М.Д. Макараў, Ад пасада да магдэбургі, s. 137-138.

${ }^{74}$ Ibidem, s. 55-59.

75 Wyniki swoich badań, rozproszone w licznych artykułach, zebrał w książce: Д. Ващук, «Абыхмо деръжали ихъ подль права ихъ земъли» (Населення Київиини та Волині і великокнязівська влада в XV-XVI cm.), Київ 2009. Zob. też: idem, «Водле обычая права земскаго»: некоторые аспекты правовой культуры украинской элиты Великого княжества Литовского в достатутовый период, [w:] Lietuvos Didžiosios Kunigaikštijos istorijos ir tradicijos fenomenai: tautu atminties vietos, Vilnius 2013, s. 93-106. 
nie przekonują. Normy widoczne w przywileju 1447 r. powtarzano w przywilejach dzielnicowych, zarówno wcześniej, jak i później - choćby w przywileju nowogródzkim. Kazimierz rzeczywiście podkreślał swoje prawa zwierzchnie wobec Kijowszczyzny ${ }^{76}$, ale raczej nie mógł ich realizować na praktyce: w całym okresie 1440-1470 r. nie jest znane żadne jego nadanie w tej ziemi ${ }^{77}$, zaś zwrócenie się bojarów kijowskich do Kazimierza za życia Olelka stanowiło wypadek wyjątkowy ${ }^{78}$. Olelko, jak i jego syn Semen, tytułował się ojczycem i hospodarem ziemi kijowskiej ${ }^{79}$, tam sądził i czynił nadania. Ważne jest jednak to, że we wszystkich potwierdzeniach Kazimierz tytułuje się królem. Jeżeli przywilej został wydany w drugiej połowie 1440 r., raczej użyto by tytułu wielkiego księcia czy królewicza. Nie przekonują też argumenty przywołane przez D. Waszczuka na poparcie datacji przywileju wołyńskiego natychmiast po śmierci Świdrygiełły (10 lutego 1452 r.). Należy raczej sądzić - za J. Jakubowskim - że dokument został wydany w pewien czas po śmierci Świdrygiełły, w wyniku skarg Wołynian na nadużycia administracji wielkoksiążęcej ${ }^{80}$, być może po spisku 1453 r., który miał na celu przekazanie ziemi łuckiej Koronie ${ }^{81}$. Porównując normy przywilejów kijowskiego i wołyńskiego z dokumentacją drugiej połowy XV w. - pierwszej połowy XVI w., autor dochodzi do wniosku, że te normy nie były jedynie martwą literą prawa, lecz działały w praktyce, otrzymując w miarę potrzeby tłumaczenia i dodatki. Niestety nie porusza on jednak ważnej kwestii: stosunku prawa ustnego wobec pisanego. W jakim sensie mówiono o prawie i zwyczaju ziemi wołyńskiej? To pozwoliłoby wyjaśnić miejsce przywilejów dzielnicowych w systemie stosunków miejscowego społeczeństwa z władzą wielkoksiążęcą. Nie rozpatrzono też stosunku przywilejów dzielnicowych do Statutów Litewskich. Autor milcząco wyszedł z założenia, że w miarę wprowadzenia w życie nowych, ogólnopaństwowych zwodów prawa przywileje traciły moc prawną. Ale - po co wtedy były potrzebne? To pytanie jest aktualne też w świetle przywilejów dla Połocczyzny i Żmudzi, które potwierdzano aż do wiek XVII i XVIII.

76 Kijów wspomniany jest - w umowie Borysa Aleksandrowicza Twerskiego z Kazimierzem IV - wśród miast, w których ten ostatni może pobierać opłaty od kupców twerskich: Lietuvos Metrika. Knyga Nr. 5 (1427-1506); Užrašymu knyga 5, wyd. E. Banionis, Vilnius 1993, № 246, s. 363 (1448-1449 r.).

77 Lietuvos metrika. Kn. 3. Vilnius 1998, passim; А. Блануца, Великокнязівська політика земельних надань на украӥнських землях Великого князівства Литовського у другій половині XV cm. (за матеріалами литовської метрики), [w:] Ukraina Lithuanica: студї̈ з історії Великого князівства Литовського, Київ 2009, s. 139-140.

78 О.В. Русина, Контроверзи історії київської княжої традииії XIII-XVI cm., [w:] eadem, Студіӥ з історії Києва та Київської землі, Київ 2005, s. 88-90.

79 С.В. Полехов, Новые документы о Киевской земле XV века, „Сфрагістичний щорічник” (Київ) Т. II: 2012, s. 265, 277.

${ }^{80}$ И.В Якубовский, op. cit., s. 287.

${ }^{81}$ Szerzej o nim zob.: O. Halecki, Ostatnie lata Świdrygiełly i sprawa wołyńska za Kazimierza Jagiellończyka, Kraków 1915. 
Przywilejem żmudzkim - po długiej przerwie w jego badaniach - zainteresował się historyk angielski, pracujący na Litwie - Stephen C. Rowell. Przeanalizował on przywileje Kazimierza Jagiellończyka (według polskiej kopii) oraz Aleksandra Jagiellończyka z 1492 r., i teksty ich opublikował w swoim artykule, łącznie z innymi źródłami o powstaniu żmudzkim lat 1440-1441. Badacz scharakteryzował pierwotny przywilej jako narzędzie integracji Żmudzi w składzie Wielkiego Księstwa Litewskiego, jednak przy zachowaniu jej świadomości regionalnej ${ }^{82}$.

Nadzwyczaj treściwe i głębokie studium całego zestawu tych dokumentów stworzył historyk litewski Eugenijus Saviščevas ${ }^{83}$. Przede wszystkim zwrócił on uwagę, że za Kazimierza Jagiellończyka powstał nie jeden przywilej dla całej Żmudzi, lecz kilka takich dokumentów, różniących się treścią i skierowanych do różnych jej krajów. Dysponujemy nie tylko znacznie zniekształconym tekstem łacińskim przywileju dla włości miednickiej oraz polskim (tłumaczeniem z ruskiego) - dla włości knetowskiej: zachowały się wzmianki o podobnych dokumentach dla innych włości. Żmudź nie stanowiła bowiem jednolitej i integralnej całości. Początki wszystkich tych przywilejów E. Saviščevas datował na koniec 1441 lub na 1442 r. - gdy trzeba było likwidować następstwa powstania. Badacz przekonująco odrzucił tezę o istnieniu przywilejów Jagiełły i Witolda dla Żmudzi. Sądzi bowiem, że na podstawie przywileju miednickiego można tylko pokusić się o rekonstrukcję treści stariny z czasów tych władców, natomiast normy przywileju knetowskiego są bardziej specyficzne, ta bowiem część Żmudzi stanowiła epicentrum powstania. Najważniejszą nowością Kazimierzowych przywilejów dla Żmudzi było według E. Saviščevasa - prawo do samodzielnego wyboru przez Żmudzinów starosty i ciwunów, co przekształciło nieformalną elitę miejscową w rządzącą elitę urzędniczą. Przywilej miednicki, lub inny zbliżony do niego, leżał u podstaw przywileju dla całej Żmudzi, wydanego dopiero przez w. ks. Aleksandra w 1492 r. Jego łaciński tekst z kolei stał się podstawą wszystkich dalszych potwierdzeń, wydawanych przez hospodarów aż po drugą połowę XVII w. Cokolwiek później E. Saviščevas opublikował razem z Dariusem Antanavičiusem nie tylko teksty zachowanych przywilejów dla Żmudzi, ale również wzmianki o niezachowanych ${ }^{84}$. We wstępie zaś prześledził rozwój tekstu przywileju żmudzkiego i osobliwości jego funkcjonowania w XVI-XVII w. przechowywania i powołań w petycjach szlachty.

Nader interesujące są też uogólnienia E. Saviščevasa na temat genezy przywilejów dzielnicowych: zakwestionował on możliwość datacji najdaw-

${ }^{82}$ S.C. Rowell, Rusena karas Žemaičiuose: keletas pastabu apie $1442 \mathrm{~m}$. privilegijos genezes, [w:] Žemaičiu praeitis, T. VIII, Vilnius 1998, s. 1-16.

83 E. Saviščevas, Žemaitijos savivalda ir valdžios elitas 1409-1566 metais, Vilnius 2010, s. 116-142.

${ }^{84}$ Žemaitijos žemés privilegijos XV-XVII a., passim. 
niejszych ich warstw na koniec XIV w. Wszystkie bowiem takie pomniki prawa powstały - jak sądzi - najwcześniej w latach 40. XV w., gdy władza hospodarska przeżywała okres słabości i była gotowa na ustępstwa wobec miejscowego społeczeństwa. Problem badań polega jednak nie na dążeniu do wykazania za wszelką cenę starożytności przywilejów dzielnicowych bądź ich powiązania z riadami dawnej Rusi, lecz na archaizmie języka przywilejów połockiego i witebskiego oraz zbieżności niektórych ich norm i - nawet - sformułowań z dokumentami XIII i XIV w. To wymaga wyjaśnienia, które przekonująco zaproponował J. Jakubowski. Wszystkie inne przywileje rzeczywiście sięgają dopiero epoki Kazimierza Jagiellończyka czy nawet Aleksandra. Wszystkie, z wyjątkiem przywileju dla powiatu bielskiego, są związane swoją genezą z wydarzeniami na początku lat 40. XV w., kiedy to w jednych ziemiach (Smoleńszczyzna, Żmudź) wybuchły otwarte powstania, natomiast w innych (Kijowszczyzna, Wołyń) odrodziły się księstwa dzielnicowe. Księstwa te następnie zlikwidowano, nadając jednak - niejako w zamian - przywileje. Wspólną cechą przywilejów jest to, że utrwalały one na piśmie kompromis hospodara $\mathrm{z}$ elitami regionalnymi. Obok zachowania stariny zawarły one normy przywileju ziemskiego z 1447 r. Dowodzi to, że kręgi rządzące Wielkiego Księstwa Litewskiego wzięły pod uwagę doświadczenia lat 30., gdy przywilej 1434 r. nie położył kresu wojnie domowej w Wielkim Księstwie Litewskim, oraz początku lat 40. - gdy ujawniła się moc dzielnicowych partykularyzmów ${ }^{85}$.

W zakończeniu nie warto powtarzać konkretnych wniosków, do których doprowadziło ostatnie półtora stulecia badań dzielnicowych przywilejów. Warto natomiast krótko podsumować i nakreślić kierunki dalszych badań. Jak pokazały odkrycia z ostatnich lat - nie wykluczone jest wprowadzenie do obiegu naukowego nowych przywilejów dzielnicowych, nie tylko tekstów poprawniejszych, ale też dokumentów zupełnie nieznanych. Nadal znaczenie zachowuje - zaproponowana przez J. Jakubowskiego - datacja i etapy rozwoju tekstów przywilejów dzielnicowych. Próby ich rewizji odniosły sukces tylko częściowy. Na specjalne studium zasługuje zagadkowy przywilej nowogródzki 1440 r., który też stawia historykom cały szereg nowych pytań.

Niezwykle obiecujące są badania funkcjonowania przywilejów dzielnicowych. Gdzie były przechowywane i kto miał do nich dostęp? W jakich wypadkach przedstawiano je hospodarowi do zatwierdzenia? Literatura przedmiotu

85 Р. Гирконтас, Гражданин ВКЛ и религия в XV веке, [w:] Наш радавод. Матэрыяльь міжнароднай навуковай канферэниы «Царква і культура народаў Вялікага княства Літоўскага і Беларусі ХІІІ-пач. ХХ стст.» (Гродна, 28 верасня - 1 кастрычніка 1992 г.), T. IV, cz. 2, Гродна 1992, s. 255. 
ogranicza się do kilku uwag ${ }^{86}$, choć problem zasługuje przecież na zbadanie w szerszym kontekście kultury prawnej, m.in. funkcjonowania prawa spisanego w Wielkim Księstwie Litewskim. Z tym wiąże się jednak inna kwestia - stopień zachowania jego przywilejów dzielnicowych. Z jednej strony, jak wynika ze studiów K. Pietkiewicza i jak się okazuje dzięki przywilejowi nowogródzkiemu czy przywilejowi na prawo magdeburskie dla Kijowa ${ }^{87}$, do Metryki Litewskiej, wbrew rozpowszechnionej opinii ${ }^{88}$, trafiały bynajmniej nie wszystkie dokumenty tego rodzaju. Z drugiej strony - przykład przywileju Henryka Walezjusza dla Żmudzi z 1574 r. pokazuje, że do tej Metryki mogły zostać wpisane dokumenty, które nie zostały ostatecznie potwierdzone przez monarchę ${ }^{89}$.

Należy też zbadać stosunek przywilejów dzielnicowych do innych aktów prawodawczych Litwy historycznej - przywilejów ziemskich, statutów litewskich, przywilejów na prawo magdeburskie, ustaw i uchwat, próśb szlachty litewskiej przedstawianych hospodarowi na sejmach, a także - do prawa zwyczajowego. Przy tym wszystkim trzeba wziąc pod uwagę dynamikę utrwalenia i rozpowszechnienia się dokumentu pisanego, którego funkcjonowanie w XV-XVI w. rozszerzało się na coraz to nowe sfery życia ${ }^{90}$. W szczególności należy wyjaśnić, jaki sens nadawano pojęciom prawa i zwyczaju ${ }^{91}$. To z kolei pozwoli ocenić, jak powszechna była znajomość przywilejów dzielnicowych $^{92}$. W świetle szczegółowych badań nad pojęciem stariny w Wielkim

${ }^{86}$ И.В. Якубовский, op. cit., s. 245-246; И.П. Старостина, Судебник Казимира 1468 г., s. 302; А. Мацук, Традыцыыя выбараў полачкага ваяводы у XVII cm., s. 120; М. Макараў, Ад nасада да магдэбургіi, s. 55-59; Žemaitijos žemés privilegijos XV-XVII a., s. 11-23.

${ }^{87}$ Н.О. Білоус, До питання про запровадження матдебурзького права в Києві, „Український історичний журнал”, 2008: № 1, s. 123-134, tamże literatura problemu; eadem, Київ напрuкінці XV-y першій половині XVII століття. Міська влада і самоврядування. Київ, 2008. Nie mogłem jeszcze skorzystać z nowej edycji przywilejów Kijowa tej autorki, Привілеї Києва кіния XV-середини XVII cm. Дослідження. Тексти, wyd. Н. Білоус, Київ 2013.

${ }^{88}$ М.М. Кром, Неизвестный привилей, s. 133-134.

${ }^{89}$ Žemaitijos žemés privilegijos XV-XVII a., s. 19, 24, 62-73.

90 Por. istotne ustalenia A.I. Hruszy: «И привильем своим потвердил». У вытокаў пісьмовай культуры Вялікага княства Літоўскага, [w:] Памяиь стагоддзяў на карие Айчыны, Мінск, 2007, zwłaszcza s. 234-236; idem, Credo quia veru: аб прычыне адсутнасиі пісьменнасці у варварскім грамадстве (метадалагічны аспект), „Беларускі гістарычны часопіс”, 2009: № 2, s. 13-14; idem, Доверял ли монарх своим подданным? (Из жизни общества Великого княжества Литовского конца XV-первой трети XVI в.), [w:] Istorijos šaltiniu tyrimai, T. III, Vilnius 2009, s. 43-84; idem, Недоверие - не из-за него ли появился письменный акт?, „Studia Slavica et Balcanica Petropolitana”, 2010: № 1(7), s. 131-156.

${ }^{91}$ Przykładowo: Lietuvos metrika. Kn. 6 (1494-1506); Užrašymu knyga 6, wyd. A. Baliulis, Vilnius 2007, № 121, s. 114 [1495 r.]; Lietuvos Metrika. Knyga 224 (1522-1530); 4-oji Teismu bylu knyga, № 280, s. 239; Д.П. Ващук «Водле обычая права земскаго», s. 105.

92 Interesujące uwagi o funkcjonowaniu I Statutu litewskiego i niektórych innych aktów prawodawczych na podstawie powołań na nie w praktyce sądowej od 1. połowy XVI w.: А.Л. Хорошкевич, "...у статут угленувши...» Из истории практического применения Первого статута Великого княжества Литовского 1529 года, [w:] Памяти Лукичева. Сборник статей по 
Księstwie Litewskim ${ }^{93}$ znów aktualny staje się stary spór o stosunek w przywilejach dzielnicowych nowiny, przeniesionej z przywilejów ziemskich, do miejscowej stariny, a także - o treść tej ostatniej. Na wnikliwe badanie zasługuje kwestia stosunku przywilejów dzielnicowych wobec Statutów Litewskich - kodeksów ogólnopaństwowych. Niekiedy milcząco przyjmuje się, że już z chwilą wprowadzenia w życie Pierwszego Statutu Litewskiego w 1529 r. przywileje dzielnicowe straciły znaczenie praktyczne, a potwierdzano je tylko na mocy tradycji. Na pierwszy rzut oka mogłoby o tym świadczyć zachowanie norm ewidentnie archaicznych, jak chociażby kunicy welna, przywilejów połockiego i witebskiego. Jednak dostosowanie ich tekstów do zmian prawa ${ }^{94}$ oraz bezpośrednie powoływanie się na nie ${ }^{95}$ w wiekach XVI i XVII świadczą, że przywileje dzielnicowe przez długi czas zachowywały ważne miejsce w świadomości narodu politycznego Wielkiego Księstwa. Wreszcie - last but not least - ważnym warunkiem takich badań obejmujących całe terytorium Wielkiego Księstwa Litewskiego - jednak z uwzględnieniem jego partykularyzmów - jest synteza osiągnięć dzisiejszych historiografii narodowych w badaniach przywilejów skierowanych do poszczególnych ziem tego państwa.

истории и источниковедению, Москва 2006, s. 80-86; I. Valikonyte, Pirmasis Lietuvos statutas Žemaitijoje, [w:] Istorijos šaltiniu tyrimai, T. III, Vilnius 2011, s. 179-194; A.B. Zakrzewski, Statuty w kulturze prawnej Wielkiego Księstwa Litewskiego, [w:] Pirmasis Lietuvos Statutas ir epocha, Vilnius 2005, s. 183-188.

${ }^{93}$ М.М. Кром, Понятие «старины» в политической и правовой культуре Великого княжества Литовского XV - XVI веков, [w:] Наш радавод. Материальи международной научной конференции по региональной истории Восточной Европь «Культура народов Великого княжества Литовского и Белоруссии. ХІІІ - нач. ХХ вв.» (Гродно, 22-24.10.1991), Т. III, cz. 3, Гродно 1991, s. 540-544; idem, “Старина» как категория средневекового менталитета (по материалам Великого княжества Литовского XIV - начала XVII вв., [w:] Mediaevalia Ucrainica: Ментальність та історія ідей, Київ 1994, s. 68-85; A. Blanutsa, D. Vashchuk, 'Old Ways' versus 'Novelties' in the Legal and Economic Sources of the Grand Duchy of Lithuania ca. 14501700, „Lithuanian Historical Studies”, T. XII: 2007, (Vilnius 2009), s. 19-40.

${ }^{94}$ Przywilej konfirmacyjny Stefana Batorego dla ziemi połockiej z 1580 r. uściśla porządek postępowania sądowego po reformach 1564-1566 r., gdy ziemia ta znajdowała się pod władzą Iwana Groźnego, А. Радаман, Полацкі земскі суд ў другой палове XVI - першай трэиі XVII в., [w:] Гісторыя і археалогія Полаика і Полачкай зямлі. Матэрыялы IV міжнароднай навуковай канферэнцыы (23-24 кастрычніка 2002 г.), Полацк 2003, s. 223.

${ }^{95} \mathrm{Na}$ stronie verso przywileju Stefana Batorego dla ziemi połockiej z 1580 r. znajduje się kilka zapisek z XVII w., m.in. o sejmiku elekcyjnym zwołanym dla wyboru wojewody połockiego w 1670 r., Архив Санкт-Петербургского Института истории Российской академии наук. Русская секция. Колл. 13. Оп. 1. Д. 312. Л. 1 об.; А. Мацук, ор. cit., s. 120; М. Макараў, Ад пасада да магдэбургіi, s. 55-59; zob. też: Žemaitijos žemés privilegijos XV-XVII a., s. 11-23. 


\title{
REGIONAL CHARTERS IN THE GREAT DUCHY OF LITHUANIA. STATE OF AFFAIRS AND RESEARCH PROSPECTS
}

\begin{abstract}
Summary
Individual regions of the Great Lithuanian Duchy were issued certain privileges, also called charters. These documents regulated the relationships between the people of Lithuania and Lithuanian great dukes, and governed the ownership system of those regions and their respective laws. Charters began to be issued already in the 1440s, and they had remained valid and in force until the beginning of the $17^{\text {th }}$ century.

The first scientific editions of regional charters appeared in the first half of the $19^{\text {th }}$ century, in Polish and Russian publications. In the second half of the $19^{\text {th }}$ century, after the uprising of 1863, interest in those monuments of the laws of the Great Duchy of Lithuania increased. This interest was caused by political reasons as the Russian Empire adopted a new course of policy and a concept of the Great Duchy being a Lithuanian-Ruthenian state, which ultimately and practically meant a Russian state. Its law was to be modelled on the Russian Justice (Russkaya Pravda) and was to be implemented in its pure, almost intact form.

The research was initiated by Russian historians from so-called Kiev school of west-Ruthenian law school (among them Fiodor I. Leontovich (1933-1911) and Michail N. Jasinsky (1862-1935). They identified three stages of development of regional privileges and established their dates. Their studies were continued at the beginning of the $20^{\text {th }}$ century by Jan Feliks Jakubowski (1874-1938), whose conclusions were subsequently adopted by Polish and Russian scientists and have remained basically unchanged till today. At the same time, in particular the last decade of the $20^{\text {th }}$ century, following a discovery of new documents, many of the earlier opinions and beliefs concerning regional charters have been verified and the scope of research widened.

Hence a number of research postulates pro futuro. What needs to be studied thoroughly are, among others, the recently discovered Novograd privilege of 1440, or the manner in which regional privileges functioned. Other questions to answer are: where were they kept, who could access them, or in which cases were they submitted for endorsement? How did they relate to other legal acts of historic Lithuania, such as land privileges, Lithuanian statutes, Magdeburg rights, gentry resolutions, statutes, requests voiced at Seym sessions, or Lithuanian customary law. The research should extend on the whole territory of the Great Duchy of Lithuania, taking into account its particularities, but should ultimately constitute a synthesis of the accomplishments of national historiographies.
\end{abstract}




\section{LES PRIVILÈGES DES PROVINCES DU GRAND-DUCHÉ DE LITUANIE. SITUATION ET PERSPECTIVES DE RESERCHE}

\section{Résumé}

Les grands princes lituaniens ont concédé des privilèges aux différents territoires (régions) de leur État. Ce type de document avait pour but non seulement de régulariser les relations entre la population, les grands princes et leurs gouverneurs (voïvodes), mais ils régissaient également le système et la loi du territoire donné. Les premiers privilèges ont vu le jour au plus tard dans les années quarante du $\mathrm{XV}^{\mathrm{e}}$ siècle, et resteront en vigueur jusqu'au XVII ${ }^{\mathrm{e}}$ siècle.

Les premières éditions savantes des privilèges des provinces paraîssent pendant la première moitié du XIX ${ }^{\mathrm{e}}$ siècle, dans les maisons d'édition russes et polonaises. Durant la deuxième moitié du même siècle, après l'insurrection de 1863, l'intérêt porté aux monuments du droit du Grand - Duché de Lituanie est de plus en plus grand. À son origine, on retrouvera la politique de l'Empire Russe et son concept du Grand - Duché de Lituanie vue comme un État lituanien et ruthène, soit finalement État russe. Par conséquent, il devait y dominer pendant bien longtemps les lois moulées sur la Prawda Ruska [Loi ruthène], dont la forme était censée de rester claire et quasiment inchangée.

Les recherches ont été entamées par les historiens de «l'école de Kiev », spécialisée dans le droit de la Ruthénie de l'Ouest (Fiodor L. Leontowicz (1833-1911), Michail N. Jasinski (1862-1935), entre autres). C'est eux qui ont identifié, fait la distinction entre les différentes étapes de l'évolution des privilèges des provinces et les ont datées. Aux débuts du $\mathrm{XX}^{\mathrm{e}}$ siècle, leurs observations seront reprises et développées par Jan Feliks Jakubowski (1874-1938) dont les conclusions ont été approuvées par la science polonaise et russe de l'époque. D'ailleurs, le projet de Jakubowski dans sa forme générale, reste valable jusqu'à nos jours. Mais depuis ce temps-là, et notamment pendant la dernière décade du $\mathrm{XX}^{\mathrm{e}} \mathrm{s}$., de nouveaux documents ont été découverts et certaines opinions classiques ont été revues, la problématique des recherches s'étant élargie.

Ainsi, il est possible de présenter quelques postulats de recherche pro futuro. Ce qui mérite une étude détaillée par exemple, c'est le privilège de Novogrod de 1440 , découvert récemment. Il conviendrait en outre se pencher sur les privilèges des provinces, définir leur fonctionnaient. Où étaient - ils conservés et qui avait accès aux privilèges? Dans quelles situations, les privilèges devaient -ils être soumis au hospodar pour validation?

A quel moment étaient -ils inscrits dans l'Acte de Lituanie [Metryka Litewska]?

Il conviendrait aussi d'identifier les rapports entre les privilèges de provinces et d'autres actes législatifs de la Lituanie historique : privilèges fonciers, statuts lituaniens, privilèges régis par le droit de Magdebourg, lois et résolutions, demandes de la noblesse lituanienne présentées au hospodar pendant la session du Sejm [chambre basse du parlement] ainsi que les rapports entre les privilèges de province et le droit coutumier. Les analyses devraient porter sur le territoire entier du GrandDuché de Lituanie, compte tenu de ses particularités. Elles devraient néanmoins constituer une synthèse des acquis des historiographies nationales. 
